\title{
OVERTOURISM PERCEPTION IN THE ISLANDS: THE CASE OF BOZCAADA AND GÖKÇEADA
}

\author{
Serdar Sünnetçioğlu *, Şefik Okan Mercan **, Ferah Özkök ${ }^{* * *} \&$ Ayşe Sünnetçioğlu ${ }^{* * * *}$
}

\begin{abstract}
In this study, it is aimed to evaluate the effects of over tourism on the two touristic islands in Çanakkale, Bozcaada and Gökçeada, from the eyes of the local people. Overtourism emphasizes that an excessive number of tourists in a particular destination can have negative effects on society. In this study, the phenomenon of overtourism has been discussed on the basis of social carrying capacity and Doxey's irridex-tolarate model. In line with this purpose, the perception of the local people about the effects of tourism, problems caused by tourists and their attitudes towards tourists were evaluated with 260 data using the survey method. The data were analyzed by performing T-Test and regression analysis in the statistical package program. According to the research findings, although there is a positive perception towards tourism in the islands, there are also problems caused by tourism. It can be said that Bozcaada is experiencing an overtourism problem due to reasons such as being a small island compared to Gökçeada. It can be said that Gökçeada is at the first stage, at the satisfaction level, although it is thought Bozcaada is the satisfaction level of Doxey's model. With this study, the social carrying capacity of the two islands in Çanakkale has been put forward theoretically, and the local people's perception of overtourism has been discussed on the basis of the Doxey theory. So, in practice, sustainable tourism planning on the islands can be done by taking these findings into consideration.
\end{abstract}

Key words: Sustainable Tourism; Resident's Behavior; Touristic Destination.

PERCEPÇÃO DO OVERTURISM NAS ILHAS: O CASO DE BOZCAADA E GÖKÇEADA

Neste estudo, o objetivo é avaliar os efeitos do "overtourismo" nas duas ilhas turísticas de Çanakkale, Bozcaada e Gökçeada, a partir dos olhos da população local. O overtourismo enfatiza que um número excessivo de turistas em um determinado destino pode ter efeitos negativos na sociedade. Neste estudo, o fenômeno do turismo excessivo foi discutido com base na capacidade de carga social e no Modelo de Irritabbilidade de Doxey. De acordo com este objetivo, a percepção da população local sobre os efeitos do turismo, os problemas causados pelos turistas e suas atitudes em relação aos turistas foram avaliados com 260 dados usando o método survey. Os dados foram analisados pelo T-Test performance e análise de regressão no programa do pacote estatístico. De acordo com os resultados do estudo, embora haja uma percepção positiva do turismo nas ilhas, também há problemas causados pelo turismo. Podese dizer que Bozcaada está enfrentando um problema de turismo excessivo por ser uma pequena ilha em comparação com Gökçeada. Pode-se dizer que Gökçeada está no primeiro estágio, no nível de satisfação, embora se pense que Bozcaada esteja no nível de satisfação do modelo Doxey. Com este estudo, a capacidade de carga social das duas ilhas em Çanakkale foi apresentada teoricamente, e a percepção da população local sobre o turismo excessivo foi discutida em termos da teoria de Doxey. Portanto, na prática, 0 planejamento do turismo sustentável nas ilhas pode ser feito levando em consideração estas descobertas.

Palavras-chave: Turismo sustentável; Comportamento dos residentes; Destino turístico.

\section{PERCEPCIÓN DEL OVERTURISM EN LAS ISLAS: LA MUESTRA DE BOZCAADA Y GÖKÇEADA}

Este estudio está dirigido a evaluar los efectos del "overturism" en las dos islas turísticas en Çanakkale, Bozcaada y Gökçeada, a partir de la pesrpectiva de las personas locales. El overturism enfatiza que un número excesivo de turistas en un destino en particular puede tener efectos negativos en la sociedad. En este estudio, el fenómeno del overturism se ha discutido sobre la base de la capacidad de carga social y el Modelo de Irritabbilidad de Doxey. En línea con este propósito, la percepción de las personas locales sobre los efectos del turismo, los problemas causados por los turistas y sus actitudes hacia los turistas fueron evaluados con 260 datos utilizando el método survey. Los datos se analizaron por la actuación de T-Test y análisis de regresión en el programa de paquete estadístico. Según los hallazgos del estudio, aunque exista una percepción positiva hacia el turismo en las islas, también existen problemas causados por el turismo. Se puede decir que Bozcaada está experimentando un problema de overturism por ser una isla pequeña en comparación a Gökçeada. Se puede decir que Gökçeada está en la primera etapa, en el nivel de satisfacción, aunque parezca que sea Bozcaada la que esté en el nivel de satisfacción del modelo de Doxey. Con este estudio, se ha propuesto teóricamente la capacidad de carga social de las dos islas en Çanakkale, y se ha discutido la percepción de las personas locales sobre el overturism en función de la teoría de Doxey. Por tanto, en la práctica, la planificación del turismo sostenible en las islas se puede hacer tomando en consideración estos hallazgos.

Palabras clave: Turismo Sostenible; Comportamiento de los Residentes; Destino Turístico.

* PhD of Tourism Administration / COMU (2016). Master in Tourism Administration / DEU (2013). Degree in Tourism / Gazi University (2011). Professor and full-time researcher at Canakkale Onsekiz Mart University, CV: https://avesis.comu.edu.tr/serdarsunnetcioglu ; Orcid: 0000-0003-0244-5874 , [ serdarsunnetcioglu@comu.edu.tr ]

${ }^{* *} \mathrm{PhD}$ of Tourism Administration/DEU (2010). Master in Tourism Administration/COMU (2006). Degree in Tourism / Mersin University (2002). Professor and full-time researcher at Canakkale Onsekiz Mart University, professor in postgraduation in Tourism Administration. CV: https://avesis.comu.edu.tr/okanmercan, Orcid: 0000-0003-1737-014X, [okanmercan@comu.edu.tr ] *** PhD of Economics / Anadolu University (1997). Master in Policy of economics / DEU (1992). Degree in Economics/Anadolu University (1988). Professor and full-time researcher at Canakkale Onsekiz Mart University, CV: https://avesis.comu.edu.tr/ferahozkok; Orcid: 0000-0002-7085-6117, [ fozkok@comu.edu.tr ]

**** PhD of Tourism Administration / COMU (2018). Master in Tourism Administration/Balikesir University (2014). Degree in Tourism / Gazi University (2011). Professor and full-time researcher at Canakkale Onsekiz Mart University, CV: https://avesis.comu.edu.tr/aysesunnetcioglu Orcid: 0000-0002-4295-9776 [ aysesunnetcioglu@comu.edu.tr ] 


\section{INTRODUCTION}

According to the UN, about 55 percent of the world's population is thought to live in an urban area or city in 2018, and this figure is expected to rise to 68 percent in the next decades (CNBC, 2020). The increase in the number of tourists visiting cities has also increased the use of natural resources causing sociocultural impact and putting pressure on infrastructure, mobility and other facilities.

However, tourism will be sustainable if it is developed and managed by considering not only the visitors but the local people, as well. At this point, particularly not including the local people in the planning process may have some negative consequences in terms of tourism plans and tourism development.

Therefore, sustainable tourism can be achieved through the participation of the local people, management of the visitors, reduction of seasonality, a careful planning and product diversification process that respects the capacity limits and characteristics of each destination (UNWTO, 2020).

The concept of overtourism expresses "the challenges of management of increased tourism flow to urban destinations and the impact of tourism on the cities and their residents" (UNWTO, 2020). Responsible Tourism Partnership defines overtourism as 'the local people's or the visitors' feeling that there are too many visitors at the destination and the quality of life or experience in the region has been unacceptably deteriorated" (Responsible Tourism Partnership, 2020).

It is possible to say that destinations are negatively affected by overtourism (González, 2018; Seraphin et al., 2018). Venice, Spain, Italy, England, Barcelona, Dubrovnik and the island of Santorini (Alexis, 2017; Coldwell, 2017; Tapper, 2017; González, 2018; Seraphin et al., 2018) are some of these destinations. Such a kind of excessive development of tourism in these aforementioned destinations causes the reaction of local people and protests against tourists have been organized (Coldwell, 2017; Tapper, 2017; Alexis, 2017). These reactions are one of the negative impacts of unplanned tourism development on the individuals (İçöz, Var \& Illhan, 2009, 82).

The phenomenon of overtourism has been evaluated in terms of stakeholders such as tourism businesses, local people, public administrators, visitors and environmentalists (Koh \& Fakfare, 2020, p. 282). In determining the number of visitors with regard to overtourism, while getting more economic returns, the required planning studies that will create less environmental and social damage should be carried out (Koh \& Fakfare, 2020, p. 281).
As a result of this, it has been confirmed that in order to identify the profitable markets, destinations must seek a better understanding of their markets, including the length of stay, spending and/or holiday purpose. Ultimately, while such kind of information creates more resilient tourism systems in terms of economic, social and environmental aspects, it may also help deal with the conflicts of overtourism (Oklevika et al., 2019, p. 1804).

The increase in the reactions to tourism across Europe has shown that tourism has the potential to cause too much negativity when not managed properly (Coldwell, 2017). This movement is also an indicator of a paradigm shift. Today, local people have started to give more importance to the quality of life than the income obtained from tourism (Croes, Rivera, Semrad, \& Khalizadeh, 2017). This situation can be considered as a proof of the inability to provide sustainability in tourism (Seraphin et al., 2018) and also as a result of ignoring the social dimension of sustainability.

It seeks to exemplify through the focus on two emblematic cases of the coastal municipality of Bahía de Banderas, Nayarit/Mexico, the social and environmental imbalance that has brought with it the development of massive sun and beach tourism fostered decades ago (Hernández and Carvalho, 2017).

\section{LITERATURE REVIEW}

In this study, it is focused on the social aspect of the carrying capacity. In literature, the social carrying capacity (SCC) is, in general, analysed both from the point of view of residents and from that of visitors. In this study, firstly, the social theory is dealt with, and then Doxey's irritation theory is explained. The theoretical frame of this study is based on the social carrying capacity theory and Doxey's irritation theory.

\subsection{Social Carrying Capacity}

In tourism, the attitude of the local people towards the tourist and tourism is highly decisive in the development of tourism. The perceptions of local people about tourism present the perspective of tourism on sustainability (Gonzalez, Coromina \& Galí, 2018, p. 277).

The local people of a region having a positive attitude are very important for the success and sustainability of tourism development (Bimonte \& Punzo, 2016). It is very difficult for the tourism activities, which are planned only by the central administrations without getting the views and support of the local people, to be successful. The views and attitude of the local people in terms of tourism raises the issue of 
carrying capacity of the related areas. It has been stated that social carrying capacity is related the perceptions of local people regarding the impacts of tourism (Gonzalez, Coromina \& Galí, 2018, p. 277).

Therefore, the tourism carrying capacity of a destination defined by UNWTO as "the maximum number of people who can visit a tourist destination at the same time without causing an unacceptable decrease in the quality and destruction of the physical, economic and socio-cultural environment" is a very important topic for tourism developers and managers. (UNWTO, 2020).

The term 'social carrying capacity' is not clearly defined in any field of science. In general, this term is always analysed in regard to a certain spatial range. This range can vary widely from, for example, the one extreme of 'global' to that of a single small spatial unit (such as one human when it comes to the individual's carrying capacity).

The correctidentification of this spatial level is a precondition for the identification of the correct measures applied in order to not exceed the carrying capacity. This applies to the social, as well as to the environmental carrying capacity (Mauerhofer, 2013, p. 70).

In general, tourism carrying capacity can be considered as the maximum number of visitors (dayvisitors and tourists) that can be contained in a tourist area (abundance carrying capacity). From the point of view of residents, SCC is the maximum number of visitors tolerated by the host population (Brandolini and Mosetti, 2002, p. 213). The other definition is "the maximum level of use that can be absorbed by an area without an unacceptable decline in the quality of experience of visitors and without unacceptable adverse impact on the area's society" (Saveriades, 2000 , p. 149).

Since the majority rule is generally used for social choices, the practical definitions of SCC are: a') the maximum number of people at the time when the majority of visitors feel comfortable with the number of other visitors on the beach; and b') the maximum number of visitors tolerated by the majority of residents (Brandolini and Mosetti, 2002: 214).

According to the news in The Guardian (2018a,b) newspaper, it is stated that mass tourism has become uncontrollable with the effects of encouraged cheap flights and cheap room rentals in historical cities in Europe. Considering the data in the related news, it can be seen that the number of tourists visiting cities such as Amsterdam, Barcelona, Florence and Prague in the last 10 years has doubled in some cities and quintupled in some and it is understood that the number of tourists has increased up to 20 times more than the population of the residents. For example, Barcelona, which hosted 30 million tourists in 2018, has a population of 1.6 million (The Guardian, 2020).

In addition to these, it is emphasized, that along with the European destinations such as Rome, Venice, Dubrovnik and Bruges, similar problems have been encountered in Far Eastern destinations such as Macchu Pichu and Bali (CNN, 2020). For example, the Maya Bay in Thailand's KoPhiPhi Island, famous for the movie The Beach, was closed when it became contaminated by the influx of tourists (The Conversation, 2020).

Graefe, Vaske and Kuss (1984) reviews the research conducted in twenty years related to social carrying capacity and they determined the factors affecting use/impact relationships: variations in tolerance to impacts, activity-specific influences, and site-spesific influences.

\subsection{Doxey's Irritation Theory}

Wang, Pfister, Morais (2006) indicates that In order to clarify the relationship between the impacts of tourism and the attitudes of the residents toward tourism, several models have been developed. One of the most influential models is the Doxey's Irridex model (1975), which addresses that, the attitude of the residents toward tourism as four stages: euphoria, apathy, irritation, antagonism.

Stage one: Euphoria; visitors and investors are welcomed and there is little planning or control mechanism. Stage two: Apathy; Tourists are taken for granted and contacts between residents and the outside become more formal; Most planning will be concerned with marketing Stage three: Annoyance; Saturation points approaching; Residents begin to show misgivings about the tourist industry. Policy makers see solutions in increasing the infrastructure rather than limiting the growth of tourism. Stage four: Antagonism; Irritations are overtly expressed verbally and physically. Mutual politeness gives way to mutual antagonism and the outsider is seen as the cause of all problems, personal and societal. Remedial planning is proceeded by the simple expedient of increasing promotion to offset the deteriorating reputation of the destination (Zhang et al., 2018: 369). 
Table 1: Doxey's Irridex model.

\begin{tabular}{|c|c|c|c|}
\hline \multicolumn{4}{|c|}{ IRRIDEX. Index of Irritation } \\
\hline Stage & Name & Attitudes & Planning \\
\hline One & Euphoria & $\begin{array}{l}\text { "Associated with the initial phase of } \\
\text { the development of the industry and } \\
\text { visitors and investors are welcomed" }\end{array}$ & $\begin{array}{l}\text { "There is usually little planning or } \\
\text { control mechanism." }\end{array}$ \\
\hline Two & Apathy & $\begin{array}{l}\text { "Tourists are taken for granted and } \\
\text { contacts between residents and } \\
\text { outsiders become more formal." }\end{array}$ & $\begin{array}{l}\text { "Most planning will be concerned } \\
\text { with marketing." }\end{array}$ \\
\hline Three & Annoyance & $\begin{array}{l}\text { "As saturation points are approached, } \\
\text { residents begin to show misgivings } \\
\text { about the tourist industry." }\end{array}$ & $\begin{array}{l}\text { "Policy makers tend to see solutions } \\
\text { in increasing infrastructure rather } \\
\text { than through setting limits } \\
\text { to growth." }\end{array}$ \\
\hline Four & Antagonism & $\begin{array}{l}\text { "This stage is reached when irritations } \\
\text { are overtly expressed verbally and } \\
\text { physically. Mutual politeness gives } \\
\text { way to mutual antagonism and the } \\
\text { outsider is seen as the cause of all } \\
\text { problems, personal and societal." }\end{array}$ & $\begin{array}{l}\text { "Planning will now have to be } \\
\text { remedial but is usually proceeded } \\
\text { by the simple expedient of } \\
\text { increasing promotion to offset the } \\
\text { deteriorating reputation of the } \\
\text { destination." }\end{array}$ \\
\hline
\end{tabular}

Source: reproduced from Alvarez-Sousa (2018:3).

In the relevant literature, it is possible to come across the studies that previously examined the overtourism perceptions of the local people. Doxey dealt with Niagara Falls in the first study that examined the negative reaction of the local population to the excessive number of visitors in 1975. (González, 2018; Seraphin et al., 2018).

According to the study carried out by Gonzalez et al. (2018), local people's perceptions of tourism differ from each considering the demographic variables. In the study, it was stated that women were more willing than men in terms of accepting more tourists. Besides, employment opportunities in tourism affect the willingness to accept more tourists.

According to the study, conducted by Muler, Gali and Coromina (2018), investigating the attitude of local people towards tourism in Besula, a historical city of Spain with a population of 2400 inhabitants, the negative effects of tourism cause a decrease in the desire of the local people to accept more tourists.

According to the study, $83 \%$ of the local people in the region where 105,000 tourists come, state that the number of tourists is more than it should be and they want less tourists. Kuscer and Mihalic (2019) revealed in their studies in Ljubljana, Slovenia that there were some negative variables, causing discomfort to local people caused by tourism effects and creating a potential excessive tourism risk.

These variables were stated as; lower quality of life, air pollution, traffic and crowd. Perkumiene and Pranskunien (2019) discussed the phenomenon of overtourism in an reintegrative study, within the scope of travel rights of tourists and from the perspective of local people's rights.

In the study, it was emphasized that the right to travel wouldn't affect the right to live; these two rights will not be intertwined and could be solved with sustainable tourism purposes in a balanced way. In their study, Smitha, Sziva and Olt (2019) measured the overtourism perception of local people in Budapest, and they stated that tourism couldn't be at the center of the infelicity of the local people.

Sousa, Pereira, Costa and Jiménez, (2014) conducted a study in Brasil to estimate the maximum number of visitors that Colares, Marudá and Murubira beaches can receive during the periods of peak visitation.

According to the findings, the maximum recommended effective carrying capacity values indicated a maximum of 674 visitors per day at Colares, 812 visitors per day at Marudá and 97 visitors per day at Murubira. In comparison with these recommendations, the observed numbers of visitors were relatively high at Marudá (885 visitors) and Murubira beaches (297 visitors), while Colares was within the suggested limit (193 visitors). So they emphasized that the density of visitors on the study beaches exceeded tolerable limits, and that coastal management measures were necessary to improve local tourist activities.

Jodhi and Dahal (2019) conducted a study on Annapurna Conservation Area (ACA), Nepal and according to this study; visitors were highly satisfied with the tourism activities. The residents were satisfied with the development of tourism in ACA, yet they perceived crowding, congestion, and cultural degradation as some form of an impending challenges in the near future.

The phenomenon of overtourism has been observed in many regions in Turkey. This situation is frequently observed in many destinations such as Antalya, Bodrum, Çeşme and Uludağ, particularly during peak seasons.

As a result of overtourism in these regions, a 
number of serious problems such as traffic, noise, security, environmental pollution, high prices and/or decrease in the quality of services, disruptions in public services, have been encountered.

In recent years, the development of tourism in Bozcaada and Gökçeada has attracted attention. It can be stated that, during the summer season, there is a tourist density particularly in Bozcaada.

A similar density has been experienced in Gökçeada for the last few years. It is possible to say that this density have created some problems for both the residents and the tourists. These problems also reflected in the national press are at such a dimension that although the islands are overcrowded and there are no vacancies in the hotels, people keep coming to the islands and sometimes there is no bread on the island (Hürriyet, 2020; Radikal, 2020; Çanakkale travel, 2020; Sözcü, 2020; İha, 2020).

Conditions are more difficult when islands host tourists above their carrying capacity. It is thought that the way to overcome this difficulty is to make a sustainable plan. Accordingly, the aim of the study is to reveal the current situation in Bozcaada and Gökçeada in order to obtain a proactive perspective and determine resident's attitudes. Therefore, the current literature provides a prediction that perception of tourism impacts may affect the negative attitude towards tourists and the following hypothesis can be written.

\section{H1: Perception of tourism impacts effect positively} negative attitude towards tourists.

\section{METHODOLOGY \& LIMITATIONS}

In this study, it has been aimed to provide a proactive perspective and determine the perceptions of the local people of Bozcaada and Gökçeada, located in the province of Çanakkale, concerning the development of tourism in the region, tourism problems and attitudes towards tourists.

Bozcaada is a district of Çanakkale, located in the northeast of the Aegean Sea. It is 4 nautical miles away from the mainland (Geyikli Pier). The circumference of the island is $38 \mathrm{~km} 2$. It is the only town that doesn't have a village in Turkey and is the 3rd largest island of Turkey. Bozcaada bears the traces of Turkish and Greek cultures. Currently, the center of the island consists of two neighborhoods called Cumhuriyet (Greek) and Alaybey (Türk). The population of Bozcaada was determined as 3 thousand 23 people in the 2018 census, however, it is stated that the population decreases to 1000 in winter (Bozcaada Belediyesi, 2019).
Figure 1: The Map of Bozcaada and Gökçeada

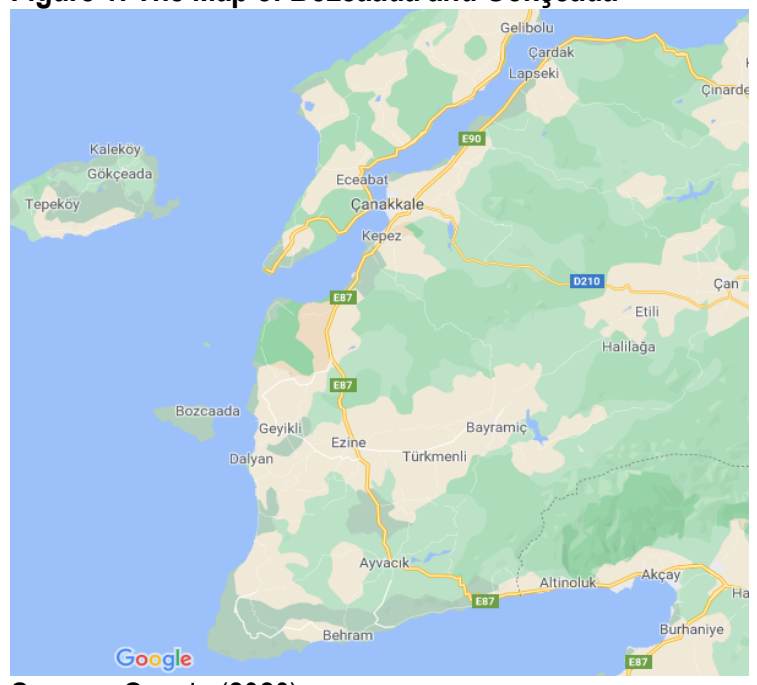

Source: Google (2020)

https://www.google.com/maps/@39.9683501,26.2157549,9 $.25 z$

Gökçeada has a total population of 9440 according to the 2019 general population census. Gökçeada, whose ancient name is Imbros (Imroz), is also the largest island of Turkey. It lies on an area of 290 square kilometers. GökçeadaKuzu Port, where the ships dock, is 32 miles away from Çanakkale and 14 miles away from Kabatepe Port on the Gallipoli Peninsula. The settlement of the people has spread to Bademli, Dereköy, Kaleköy, Tepeköy, Zeytinli Village, Şahinkaya, Şirinköy, Uğurlu, Yeni Bademli and Eşelek other than the island center and it is the fourth island in the world in terms of the abundance of water resources (Gökçeada Kaymakamlığı, 2020). What's more, Gokceadawith the Cittaslow title that it took in June 2011 became the first and only cittaslow island in the world (Cittaslow Türkiye, 2020).

In the study designed to be a descriptive one, the data were collected through a questionnaire developed based on the literature. The questionnaire was applied in Bozcaada and Gökçeada districts of Çanakkale and as online to the people reached on social media platforms that include local residents of the respective districts between the dates 25.12.2019 and 20.02.2020. Within this context, a total of 300 people were reached using the convenience sampling method.

However, 40 questionnaires were excluded from the analysis because they were either sloppy or filled incompletely, and analyzes were conducted over 260 questionnaires. In the study, in order to measure the perceptions of local people on the effects of tourism, 12 expressions, six of which are positive and six of which are negative, were used from the scale created by Muler, Gali, and Coromina (2018). Within the scope of the research, the scale related to tourism-related problems and Doxey's satisfaction-hostility scale were 
adapted from Szromek, Kruczek and Walas (2019). The reaction categories of the items were subjected to a 5-Likert scale.

\subsection{Reliabilty}

In order to test the reliability, Cronbach's Alpha ( $\alpha$ ) values were examined for all the scales, and item total correlations and multiple explanatory coefficients were examined in the reliability analysis for the whole questionnaire.

According to this, in the perception the effects of tourism scale, "The workplaces on the islands are mostly for tourists." and "Prices have increased on the island because of tourism." expressions were removed because their item total correlations were below 0.200 , and the overall reliability of the scale is, 75 . In the scale of tourism problems, the expressions "High property prices", "Lack of entertainment options" and "Lack of local stores" were removed because the item total correlations were below 0.200 .

In the reliability analysis carried out subsequently, the overall reliability of the scale was calculated as, 77 . The Cronbach Alpha value of Doxey's satisfactionhostility scale was found to be ,78. Thus, it can be concluded that the data obtained from the scales are reliable. When it is removed from all scales, it was determined that there was no item that would significantly increase the reliability coefficient. Thus, it is determined that the data obtained from the scales are reliable.

\subsection{Validity}

In order to collect valid data in the research, a number of measures have been taken and some applications have been made. These applications are briefly explained below. Translation-retranslation application was carried out. The scales are originally in English.Translation from English to Turkish was carried out by experts in the field. A face-to-face interview was conducted with 5 people to test its clarity.

In order to test the validity of the scales used in the study factor analysis was applied. First of all, the construct validity was tested and the confirmatory factor analysis was applied after the explanatory factor analysis. In the explanatory factor analysis (EFA); coherence values regarding each item are expected to be 0.500 and over.

It has been stated that it is appropriate for each item to have a load of at least 0.400 on the factor to which it belongs (Alpar, 2013, p. 276-277). In determining the number of factors, the eigenvalue $(\geq 1)$ was taken into consideration and the Varimax rotation method was used. In social sciences, it is generally accepted to be sufficient if the variance explained is between 0.40-0.60 (Alpar, 2016, p. 617). The KMO value must be at least .60 and over in order for the sample size to be sufficient, and Barlett test should be significant, as well $(p<.05)$ (Tabachnick \& Fidell, 2013).

After presenting the construct validity, convergent validity and discriminant validity were analyzed. For the convergent and divergent validity of the scale, the explained mean variance (AVE) and internal consistency reliability (CR) values of each factor were calculated. It is expected that the regression values arranged in the confirmatory factor analysis should not be over 1 and the $t$ value should be at least 1.96 (Şimşek, 2007, p. 86). It has been stated that the fit indices CMIN / DF, CFI, GFI and RMSEA could be used in the analysis (Şimşek, 2007, p. 13; Tabachninck \& Fidell, 2015, p. 725; Karagöz, 2017, p. 467).

The perception regarding the effects of tourism explains $55.5 \%$ of the total variance in two dimensions. The first dimension has been named as "Negative Perception". The extraction values obtained as a result of principal components analysis are between 498.647, while factor loadings are between .693-, 792. The second dimension has been named as "Positive Perception". In this dimension, extraction values obtained as a result of principal components analysis are between 481-, 596, while factor loadings are between .498-, 570 .

The values obtained show that the relation of the items (variables) with the relevant factor is at a good level. When the confirmatory factor analysis results were examined, it was found that the t-values of all items were greater than 1.96, the lowest combined reliability for the first dimension was 0.83 and the AVE value was 0.56 ; for the second dimension, the $C R$ value is 66 and the AVE value is 33 . When the goodness of fit is considered $\left(x^{2}=310,377, \quad x^{2} / s d=1.447\right.$, RMSEA $=0.42$, AGFI $=0.952, \mathrm{CFI}=0.979 ; \mathrm{GFI}=0,975)$, it determined that the AFA result has been confirmed.

Scale according to EFA applied to test the validity of Attitude Expressions towards Tourist according to Doxey model; (KMO: 0.733; Barlett Sphericity test $\chi 2$ : 1279.174; s.d.3; $p<0.001$ ) shows a one-dimensional structure and explains $59.480 \%$ of the total variance.

The extraction values obtained as a result of principal components analysis are between 516-, 819, while factor loadings are between .718-, 903. As the result of EFA, only negative expressions form a single dimension, the scale was named as Negative Attitude towards Tourists. Since the model was determined to be a saturated model in CFA, goodness of fit could not be obtained.

Saturated model is a model in which there is only one solution for some parameters and the degree of freedom is zero since there is sufficient information in 
the sample covariance matrix (Doğan, 2015, p. 14). The CR value calculated for the scale is 0.86 and the AVE value is 0.68 . Accordingly, it confirms that the Negative Attitude toward Tourist scale is onedimensional and measures a single feature.

As a result of the analysis conducted to test the validity of the Tourist Related Problems scale; "I am happy that tourists visit this place because it means income, new connections, employment and prestige for the region." and "It is normal for tourists to visit this place does not affect me in anyway." statements were removed because of factor loadings are low.

After, KMO sampling adequacy was calculated as $72.6 \%$. Bartlett test results calculated for the scale are also significant at $p<0.0001$ level. It was determined that the data obtained from the scale were suitable for factor analysis. The Tourist Related Problems scale explains $64.2 \%$ of the total variance in four dimensions.

The first dimension is called "Environmental Problems". The extraction values obtained as a result of principal component analysis are between 490- .693, while factor loadings are between, 588-,825.

In the second dimension called "Price Increase", the extraction values obtained as a result of principal component analysis are between 605-, 759, while factor loadings are between ,643-,869.

The third dimension has been named "Security". In this dimension, extraction values obtained as a result of principal components analysis are between ,544,681, while factor loadings are between ,734-,796.

The fourth dimension was named "Traffic", and as a result of the principal components analysis, the extraction values were calculated as $685-, 774$, factor loads, 811-, 869.

The values obtained show that the relation of the items (variables) with the related factor is good. When the confirmatory factor analysis results were examined, it was found that the t-values of all items were greater than 1.96 , the combined reliability for the first dimension was 0.79 and the AVE value was 0.50 ; the combined reliability for the second dimension was 82 , the AVE value was 61 ; The reliability was calculated as 80 , AVE value, 58; for the fourth dimension, the composite reliability, 82 , AVE value, 70 . Considering the goodness of fit $\left(x^{2}=98.604, x^{2} / d f=2.098\right.$, RMSEA $=.065$, AGFI $=0.896 . \mathrm{CFI}=0.931, \mathrm{GFI}=0.937)$, the AFA result is determined to be confirmed.

\section{ANALYSIS AND DISCUSSION}

Findings regarding the descriptive features of the research sample are given in Table 2. When we look at the sample of the research, it is seen that there are slightly more male participants, people between the ages of 31-39 are the majority, their income is mostly in the range of $2325-6700 \mathrm{TL}$, the working situation is mostly private sector, and this is evenly distributed in tourism and non-tourism sectors, they usually live on the island for 11 years or more.

Table 2. Descriptive characteristics of the participants

\begin{tabular}{|c|c|c|c|c|c|}
\hline & $\mathrm{N}$ & $\%$ & & $\mathrm{~N}$ & $\%$ \\
\hline \multicolumn{3}{|l|}{ Gender } & \multicolumn{3}{|c|}{ Years lived on the island } \\
\hline Female & 116 & 44,6 & $0-5$ years & 65 & 25 \\
\hline Male & 142 & 54,6 & $6-10$ years & 50 & 19,2 \\
\hline \multirow[t]{2}{*}{ Missing data } & \multirow[t]{2}{*}{2} & \multirow[t]{2}{*}{,08 } & $\begin{array}{l}11 \text { years and } \\
\text { above }\end{array}$ & 142 & 54,7 \\
\hline & & & Missing data & 3 & 1,1 \\
\hline \multicolumn{3}{|l|}{ Age } & \multicolumn{2}{|l|}{ Income } & \\
\hline $18-20$ & 13 & 5 & $0-2324 \mathrm{TL}$ & 58 & 22,4 \\
\hline $31-39$ & 119 & 45,7 & $\begin{array}{l}2325-6700 \\
T L\end{array}$ & 134 & 51,6 \\
\hline 40 ve 57 & 86 & 33,2 & $\begin{array}{l}6700 \text { TL and } \\
\text { above }\end{array}$ & 62 & 23,8 \\
\hline 58 and above & 40 & 15,3 & Missing data & 6 & 2,2 \\
\hline Missing data & 2 &, 8 & \multicolumn{3}{|l|}{ Occupation } \\
\hline \multicolumn{3}{|l|}{ Education } & $\begin{array}{l}\text { Public } \\
\text { employee }\end{array}$ & 50 & 19,2 \\
\hline $\begin{array}{l}\text { Primary and } \\
\text { secondary }\end{array}$ & 60 & 23,7 & $\begin{array}{l}\text { Working in } \\
\text { the tourism } \\
\text { industry }\end{array}$ & 57 & 22 \\
\hline Undergraduate & 59 & 22,7 & $\begin{array}{l}\text { working in the } \\
\text { non-tourism } \\
\text { private sector }\end{array}$ & 56 & 21,5 \\
\hline $\begin{array}{l}\begin{array}{l}\text { Bachelor } \\
\text { degree }\end{array} \\
\end{array}$ & 98 & 37,6 & Retired & 54 & 20,7 \\
\hline $\begin{array}{l}\text { Postgraduate } \\
\text { education }\end{array}$ & 36 & 13,8 & $\begin{array}{l}\text { Student or } \\
\text { unemployed }\end{array}$ & 39 & 15 \\
\hline Missing data & 7 & 2,6 & Missing data & 4 & 1,6 \\
\hline \multicolumn{3}{|l|}{ Living Island } & & & \\
\hline Gökçeada & 171 & 65,7 & & & \\
\hline Bozcaada & 87 & 33,5 & & & \\
\hline Missing data & 2 & 0,8 & & & \\
\hline
\end{tabular}

Source: own elaboration.

The average of the responses of the people of Bozcaada to the statements containing negative attitudes towards tourists is higher than that of Gökçeada (Table 3).

In Gökçeada residents disagree with any negative statements, but Bozcaada residents mostly agree the first two statements of negative attitude. We understand that in Bozcaada, residents do not agree with antagonism expressions. It can be said that they are in the annoyance stage but not the antagonism stage yet, according to Doxey's theory.

It can be mention that the presence of a negative perception of tourism among the local people living on the islands ( $\bar{x}: 3.38 / 5.00$; test value: 3 : t: 5.649 ; $p$ (twoway): 0.000). However, it can be said that neither the presence of a positive perception of tourism among the local people living on the islands, nor the absence of it $(\bar{x}: 2.89$ / 5.00; test value: 3 : t: $-1.605 ; p$ (two-way): $0.011)$. 
Table 3. Comparison of Negative Attitude towards Tourists by Islands

\begin{tabular}{|l|c|c|}
\hline & $\begin{array}{c}\text { Gökçeada } \\
\bar{x}\end{array}$ & $\begin{array}{c}\text { Bozcaada } \\
\bar{x}\end{array}$ \\
\hline $\begin{array}{l}\text { Unfortunately, I think that tourists } \\
\text { coming to the region have negative } \\
\text { effects rather than positive effects. }\end{array}$ & 2,73 & 3,33 \\
\hline $\begin{array}{l}\text { Currently, tourists cause more } \\
\text { problems. Their large number reduces } \\
\text { the comfort of the locals. }\end{array}$ & 2,65 & 3,26 \\
\hline
\end{tabular}

\begin{tabular}{|l|l|l|}
\hline I can't stand seeing tourists around me. & 1,78 & 2,18 \\
\hline
\end{tabular}

Source: own elaboration.

It is stated that tourism is an important source of income for the islands. It has been determined that tourists from different nationalities make the island more attractive. However, it is seen that the environmental pollution and noise pollution caused by tourism make life on the island less enjoyable.

Table 4. T-Test results for perception of tourism effects

\begin{tabular}{|l|c|c|c|c|}
\hline & $\overline{x a}$ & $\mathrm{~s} . d$ & $\mathrm{t}$-valueb & $\begin{array}{c}\mathrm{p} \text {-value } \\
\text { (two-way) }\end{array}$ \\
\hline Due to tourism, crime rate is increasing on the island. & 2,93 & 1,490 &,- 749 &, 454 \\
\hline The noise caused by tourism makes life on the island less enjoyable. & 3,38 & 1,480 & 4,190 & $\mathrm{p}<0,0001$ \\
\hline Thanks to tourism, cultural heritage is well protected. (R) & 2,87 & 1,485 & $-1,379$ &, 169 \\
\hline Tourism brings more money to the island than any other industry. (R) & 4,02 & 1,236 & 13,225 & $\mathrm{p}<0,0001$ \\
\hline Tourists are truly learning about and learning about the island's cultural heritage. (R) & 3,00 & 1,340 &, 046 &, 963 \\
\hline Thanks to tourism, people have more leisure activities. (R) & 2,98 & 1,329 &,- 187 &, 852 \\
\hline Tourists create obstacles to the lives of the locals on the island. & 3,20 & 1,482 &, 138 &, 033 \\
\hline Tourists pollute the island. & 4,02 & 1,338 & 12,213 & $\mathrm{p}<0,0001$ \\
\hline a: Response categories: 1 : Definitely Disagree,...,5: Definitely Agree b: Test value: $3 ;$ n:260; f.d.: 259 & & \\
\hline
\end{tabular}

Source: own elaboration.

Table 5. T-Test results of Tourist Related Problems

\begin{tabular}{|l|c|c|c|c|}
\hline & $\overline{x a}$ & s.d & $\begin{array}{c}\text { t- } \\
\text { valueb }\end{array}$ & $\begin{array}{c}p \text {-value } \\
\text { (two-way) }\end{array}$ \\
\hline $\begin{array}{l}\text { Scarcity of } \\
\text { parking } \\
\text { spaces }\end{array}$ & 4,33 & 1,106 & 19,243 & $p<0,0001$ \\
\hline $\begin{array}{l}\text { Traffic } \\
\text { congestion }\end{array}$ & 4,24 & 1,174 & 17,041 & $p<0,0001$ \\
\hline High rents & 4,45 &, 942 & 24,790 & $\mathrm{p}<0,0001$ \\
\hline $\begin{array}{l}\text { High property } \\
\text { prices }\end{array}$ & 4,35 & 1,051 & 20,643 & $\mathrm{p}<0,0001$ \\
\hline Air pollution & 3,66 & 1,504 & 7,105 & $\mathrm{p}<0,0001$ \\
\hline Garbage & 4,54 &, 936 & 26,542 & $\mathrm{p}<0,0001$ \\
\hline $\begin{array}{l}\text { Price increase } \\
\text { in goods and } \\
\text { services }\end{array}$ & 4,49 &, 874 & 27,413 & $\mathrm{p}<0,0001$ \\
\hline $\begin{array}{l}\text { Noise } \\
\text { pollution }\end{array}$ & 4,12 & 1,157 & 15,576 & $\mathrm{p}<0,0001$ \\
\hline $\begin{array}{l}\text { Too much } \\
\text { water use }\end{array}$ & 4,33 & 1,028 & 20,843 & $\mathrm{p}<0,0001$ \\
\hline $\begin{array}{l}\text { More places } \\
\text { where alcohol } \\
\text { is consumed }\end{array}$ & 2,99 & 1,598 &,- 117 &, 907 \\
\hline $\begin{array}{l}\text { Security issue } \\
\text { (fight, } \\
\text { argument, etc.) }\end{array}$ & 3,84 & 1,310 & 10,343 & $\mathrm{p}<0,0001$ \\
\hline $\begin{array}{l}\text { Having noise } \\
\text { at night }\end{array}$ & 3,72 & 1,381 & 8,414 & $\mathrm{p}<0,0001$ \\
\hline $\begin{array}{l}\text { a: Response categories: 1: Definitely Disagree, ..,5: } \\
\text { Definitely Agree; b: Test value: 3; n:260; f.d.: } 259\end{array}$ \\
\hline
\end{tabular}

Source: own elaboration.

Participants are neutral about whether to ignore the negativities that tourism can bring to the island, as it provides money and job opportunities. They were also undecided as to whether tourism enables the protection of cultural heritage and the transfer of cultural heritage to tourists. The presence of tourists neither prevents nor hinders the life of the local people on the island.

Participants stated that tourism creates some problems in Gökçeada and Bozcaada. These problems in the field of transportation; The scarcity of parking spaces, traffic congestion, and crowds in public transport are manifested. It is stated that tourism causes an increase in property prices and real estate rents and creates a short-term flat rental problem.

However, tourism creates an e inflationist pressure; it can be said that there is an increase in prices of goods and services. Tourism has been evaluated as an important cause of pollution. It is possible to state that it creates air, noise and environmental pollution. Excessive water use was addressed as an emerging problem. Experiencing security-related problems at the destination (fighting, argument, etc.) is considered as another tourismrelated problem.

When the T-Test results in Table 7 are examined, it is possible to say that there is a positive attitude towards the tourist. Participants living on the islands are happy with the arrival of tourists as they provide income, new connections, employment and prestige for the region. They do not feel uncomfortable seeing tourists around them. They state that the visits of tourists do not affect them. However, they were undecided that the arrival of tourists to the region had negative effects rather than positive effects. 
Table 6. T-Test results of Negative Attitude towards Tourist Expressions

\begin{tabular}{|c|c|c|c|c|}
\hline & $\overline{x a}$ & s.d & $\begin{array}{l}\mathrm{t}- \\
\text { value }^{\mathrm{b}}\end{array}$ & $\begin{array}{c}\text { p-value } \\
\text { (two- } \\
\text { way) }\end{array}$ \\
\hline $\begin{array}{l}\text { Unfortunately, I think } \\
\text { that tourists coming to } \\
\text { the region have } \\
\text { negative effects } \\
\text { rather than positive } \\
\text { effects. }\end{array}$ & 2,92 & $\begin{array}{c}1,43 \\
4\end{array}$ & -867 & ,387 \\
\hline $\begin{array}{l}\text { Currently, tourists } \\
\text { cause more } \\
\text { problems. Their large } \\
\text { number reduces the } \\
\text { comfort of the locals. }\end{array}$ & 2,85 & $\begin{array}{c}1,51 \\
1\end{array}$ & $-1,604$ & 110 \\
\hline $\begin{array}{l}\text { I can't stand seeing } \\
\text { tourists around me. }\end{array}$ & 1,91 & $\begin{array}{c}1,27 \\
4 \\
\end{array}$ & $\begin{array}{c}- \\
13,751 \\
\end{array}$ & $\begin{array}{r}p<0,00 \\
01 \\
\end{array}$ \\
\hline $\begin{array}{l}\text { a: Response catego } \\
\text { Definitely Agree; b: }\end{array}$ & 1: D & 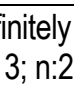 & $\begin{array}{l}\text { sagree } \\
\text { f.d.: } 2\end{array}$ & \\
\hline
\end{tabular}

Source: own elaboration.

One-way ANOVA analysis was conducted to test whether there is a difference in tourism perception according to the occupational groups of the participants. According to the analysis results there was no difference between the occupational groups and the negative perceptions between the groups. Differences between groups were observed in positive perception $(p<0.05)$.

According to the analysis results, the groups with positive perceptions are the student and unemployed group $(\bar{x}=3.40)$ and those working in the tourism sector $(\bar{x}=3.08)$. The positive perception of public employees $(\bar{x}=2.95)$, other sector employees $(\bar{x}=2.76)$ and retirees $(\bar{x}=2.42)$ is low.

There is a significant difference between the student and unemployed group and the public worker, non-tourism private sector and retired group $(p<0.05)$. There are significant differences between public employees and the student and unemployed group and the retired group $(p<0.05)$.

There is a significant difference between tourism sector employees and retirees $(p<0.05)$. And finally, significant differences were found between retirees, students and unemployed groups, public employees and tourism workers groups $(p<0.05)$.

According to the results of the one-way ANOVA analysis, which shows whether there is a difference in the negative attitude towards the tourist according to the occupational groups of the people, it is seen that the tourism sector employees have a negative attitude towards the tourists much less than the other groups (for private sector $\bar{x}=2.14$; for public worker $\bar{x}=2.84$; for non-tourism private sector $\bar{x}=2.50$; for retired $\bar{x}=$ 2.74).
Although the negative attitude averages of other groups are also below 3, there is a statistically significant difference especially between tourism sector employees and students and unemployed, public employees and retirees $(p<, 01)$.

It was tested whether the positive perceptions differed according to the years lived on the island, and accordingly, it was observed that those who lived on the island for $1-5$ years remained indecisive $(\bar{x}=2.93)$. It was determined that those who lived 11 years and over had a positive perception towards tourists $(\bar{x}=2.73)$, while those living between $6-10$ years $(3.29)(p<, 05)$. Therefore, there is a significant difference between those who have lived on the island for 6-10 years and those who have lived for 11 years or more.

The negative perception dimension differs according to the year the local people lived in the region $(p<, 01)$. There is a significant difference in perceptions of those who live 11 years and above $(\bar{x}=3.57)$ compared to those who have lived for $1-5$ years $(\bar{x}=$ 3.09).

As a result of the analyzes made to test whether there is a difference according to gender, it is seen in Table 7 that women have more negative perceptions and less positive perceptions. In negative attitude towards tourists, the average of women is higher than men.

Table 7. Results of independent sample T-Test by gender

\begin{tabular}{|c|c|c|c|c|c|}
\hline & Gender & $\mathrm{N}$ & $\bar{x}$ & S.D & $p$ \\
\hline \multirow{2}{*}{$\begin{array}{l}\text { Negative } \\
\text { Tourism } \\
\text { Perception }\end{array}$} & Female & 116 & 3,5517 & 1,13 & \multirow[b]{2}{*}{$\begin{array}{l}0,03 \\
2\end{array}$} \\
\hline & Male & 142 & 3,2570 & 1,05 & \\
\hline \multirow{2}{*}{$\begin{array}{l}\text { Positive } \\
\text { Tourism } \\
\text { Perception }\end{array}$} & Female & 116 & 2,7047 & 1,03 & \multirow[b]{2}{*}{$\begin{array}{l}0,00 \\
7\end{array}$} \\
\hline & Male & 142 & 3,0546 & 1,00 & \\
\hline \multirow[b]{2}{*}{$\begin{array}{l}\text { Negative } \\
\text { Attitude } \\
\text { For } \\
\text { Towards } \\
\text { Tourists }\end{array}$} & Female & 116 & 2,8420 & 1,21 & \multirow[b]{2}{*}{$\begin{array}{l}0,00 \\
1\end{array}$} \\
\hline & Male & 142 & 2,3427 & 1,07 & \\
\hline
\end{tabular}

Source: own elaboration.

It is seen in Table 8 that a significant difference is detected in terms of all variables for living island as a result of the independent sample t-test. It was observed that the average of negative perceptions of those living in Bozcaada was higher than those living in Gökçeada, and that their positive perception was also higher. In the negative attitude towards tourists, it is seen that Gökçeada residents do not have such an attitude $(\bar{x}=$ 2.38), while the average of those living in Bozcaada is close to $3(\bar{x}=2.92)$, so it can be said that there is indecision. 
Table 8. Independent Sample T-Test for living island results

\begin{tabular}{|c|c|c|c|c|c|}
\hline & $\begin{array}{l}\text { Living } \\
\text { Island }\end{array}$ & $\mathrm{N}$ & $\bar{x}$ & S.S & $P$ \\
\hline \multirow{2}{*}{$\begin{array}{l}\text { Negative } \\
\text { Tourism } \\
\text { Percepiton }\end{array}$} & Gökçeada & 171 & 3,13 & 1,11 & \multirow[b]{2}{*}{0,000} \\
\hline & Bozcaada & 87 & 3,89 & 89 & \\
\hline \multirow{2}{*}{$\begin{array}{l}\text { Positive } \\
\text { Tourism } \\
\text { Perception }\end{array}$} & Gökçeada & 171 & 2,79 & ,95 & \multirow[b]{2}{*}{0,022} \\
\hline & Bozcaada & 87 & 3,10 & 1,14 & \\
\hline \multirow{2}{*}{$\begin{array}{l}\text { Negative } \\
\text { Attitude For } \\
\text { Towards } \\
\text { Tourists }\end{array}$} & Gökçeada & 171 & 2,38 & 1,15 & \multirow[b]{2}{*}{0,000} \\
\hline & Bozcaada & 87 & 2,92 & 1,11 & \\
\hline
\end{tabular}

Source: own elaboration.

An independent sample T-Test was conducted to reveal whether the dimensions of perceived tourism problems differ between the islands and the results are given in Table 10. It has been observed that there is only a difference in terms of security in terms of variables. Accordingly, people living in Bozcaada have more security problems than Gökçeada residents. In other dimensions, it is seen that both islands perceive problems in terms of related variables.

Table 9. T-Test results regarding the comparison of tourist related problems by islands

\begin{tabular}{|c|c|c|c|c|c|}
\hline & Gender & $\mathrm{N}$ & $\overline{\mathrm{X}}$ & $\mathrm{S} . S$ & $\mathrm{P}$ \\
\hline \multirow{2}{*}{$\begin{array}{c}\text { Environental } \\
\text { Problems }\end{array}$} & Gökçeada & 171 & 4,23 &, 82 & \multirow{3}{*}{0,79} \\
\cline { 2 - 6 } & Bozcaada & 87 & 4,02 &, 91 & \\
\hline Security & Gökçeada & 171 & 3,21 & 1,12 & \multirow{2}{*}{0,00} \\
\cline { 2 - 5 } & Bozcaada & 87 & 4,10 &, 82 & \\
\hline High Prices & Gökçeada & 171 & 4,42 &, 82 & \multirow{2}{*}{0,09} \\
\cline { 2 - 5 } & Bozcaada & 87 & 4,42 &, 67 & \multirow{2}{*}{0,12} \\
\hline \multirow{2}{*}{ Traffic } & Gökçeada & 171 & 4,23 & 1,05 & \multirow{2}{*}{0,40} \\
\cline { 2 - 5 } & Bozcaada & 87 & 4,41 &, 80 & \multicolumn{2}{|c}{} \\
\hline
\end{tabular}

Source: own elaboration.

According to this finding, Bozcaada, which is a smaller island than Gökçeada, has a taverns street in the city center. So, in Bozcaada, tourists drink alcohol during the night in this small area. But Gökçeada is a bigger island and the tourists are spread over a wider area therefore the social carrying capacity is more difficult to exceed.

Correlation analysis was performed to test whether there is a relationship between variables. It was determined that there is, a negative and weak relationship $(r=-244)$ between positive perception and negative perception; negative and weak relationship between positive perception and negative attitude towards tourists $(r=-, 296)$; and a moderate positive relationship between negative perception and negative attitude towards tourists $(r=, 576)$.

According to the results of the regression analysis performed to determine the effect of positive perception and negative perception dimensions, which are the sub-dimensions of the tourism perception variable, on the negative attitude towards the tourist, is statistically significant $(p<0.0001)$.

As seen the Table 11, the positive perception and negative perception it was understood to explain $35.2 \%$ of the change in negative attitude towards the tourist. On the other hand, each 1-unit increase in positive perception will cause a -,165 unit decrease in negative attitude towards tourists $(\beta=-, 165)$ On the other hand, each 1-unit increase in negative perception will cause an increase of 536 units $(\beta=, 536)$.

This result shows that the local people's perception of the positive aspects of tourism is effective on their attitude towards tourists. Well, how will it be? The philosophy to be developed in order to bring the people of the region together with the positive blessings of tourism and to show a positive attitude towards tourists, is the philosophy of sustainable tourism.

Accordingly, it is to ensure that the social carrying capacity in the region is not exceeded. In this way, overtourism will disappear by itself, and a model that satisfies the local population will emerge, with a small number of destinations with good quality.

Table 10. Regression analysis

\begin{tabular}{|l|l|l|l|l|l|}
\hline & \multicolumn{2}{|l|}{ Unstandardized coefficient } & Standardized coefficient & \multirow{2}{*}{ t value } & P value \\
\cline { 2 - 5 } & $\mathrm{B}$ & Standart Error & Beta & & , \\
\hline Constant & 1,175 &, 287 & & 4,100 &, 000 \\
\hline Positive Tourism Perception &,- 187 &, 059 &,- 165 & $-3,189$ &, 002 \\
\hline Negative Tourism Perception &, 569 &, 055 &, 536 & 10,368 &, 000 \\
\hline Dependent variable: Negative Attitude For Towards Tourists: R: 0,598 R2:0,357; Adjusted R2: 0,352; D-W: 1,954; F= 71,140;p<0.0001 \\
\hline
\end{tabular}

Source: own elaboration.

\section{CONCLUSIONS AND IMPLICATIONS}

There are many studies on the use of resources and the negativities that arise in the living conditions of the local people with the increase in the number of tourists coming in the destinations where tourism develops (González, 2018; Seraphin et al., 2018; Muler, Gali, \& Coromina, 2018), Kuscer \& Mihalic, 2019). A significant part of these studies focuses on the concept of overtourism. It can be said that the negative effects of overtourism are higher especially in destinations with limited land parts such as islands. 
Taking social carrying capacity perspectives it can be said that it was determined that tourism is an important source of income for the islands for the local people, tourists from different nationalities make the island more attractive, whereas the environment and noise pollution caused by tourism make life on the island less enjoyable. These results are very important in terms of tourism perspective and sustainable planning of the islands.

On the other hand, these results are similar to the results of the study conducted by Kuscer and Mihalic (2019). In the related study, it was determined that local people perceive problems such as quality of life, air pollution, traffic and crowd.

Another noticeable finding in the study findings was that women stated that the effects of tourism were more negative than men and their attitudes towards tourists were more negative. This may be because women have a more emotional approach.

When the research findings are evaluated, it is seen that the local people in Gökçeada approach more positively than those in Bozcaada in terms of their perceptions about the development of tourism, their problems regarding tourism and their attitudes towards tourists.

When this situation is evaluated in terms of social carrying capacity, if the crowd of tourists does not affect the life of the local people negatively, the view of tourism continues to be positive.when people decide an area is crowded; they indirectly compare with their situation with their perception what is acceptable (Vaske \& Donnely, 2002)

In addition, this situation can be explained according to Doxey's Tolerance model. As long as the number of tourists and their total effects remain below a certain level, most of the locals accept tourists and approach them welcoming.

However, when the level of satisfaction is exceeded, various discontents arise and a tendency from apathy to hostility occurs. When the results of the study are evaluated in terms of the model in question, it can be said that Gökçeada is at the first stage, at the satisfaction level, although it is thought Bozcaada is the satisfaction level.

It can be said that Bozcaada is experiencing an overtourism situation due to reasons such as being a small island compared to Gökçeada and being easier to transport, having temporal and spatial concentration, being at the forefront in terms of social visibility, and therefore the local people have not started to reach the level of satisfaction gradually.

The results of the research also show that during the stages in Doxey's model, the local people of Bozcaada are not at the level of hostility but almost the level of anger. This situation reveals the necessity to take some precautions regarding the issue. Some measures have been taken to avoid congestion in the center of the island (prohibition of vehicle entry to the center, creating an appointment for the ship).

However, calculating the carrying capacity of the island, ensuring that the carrying capacity is not exceeded in the number of people coming to the island, focusing on tourists who will stay on the island for a longer time instead of daily tourists, prolonging the season with alternative tourism types (gastronomy tourism, agro-tourism) and It is also recommended to carry out studies to spread it throughout the year.

In Gökçeada, the situation is seen as more positive in terms of extreme tourism. The reasons for this can be shown as the relatively more difficult access to the island, the large surface area of the island, the demand for diving tourism and water sports activities besides sun-sea-sand tourism.

In this way, the temporal and spatial density is reduced. However, although it is a more positive approach compared to Bozcaada, it has been observed that local people perceive problems related to the environment caused by tourism, increase in prices and traffic.

This situation may cause the overtourism in the future if Gökçeada becomes more popular and hosts more tourists. At the same time, on the island, which is a slow city, it is considered important to make a sustainable planning without being late, taking into account the criteria of slow cities.

There are some limitations in this study. As mentioned before, there is a decrease in the number of people living on the islands during the winter months. Therefore, the sample size of the study was limited. This situation creates an obstacle to the generalizability of the study. Collecting the data of future studies in the summer months may prevent a limited sample size.

In other studies, the subject can be examined in depth by conducting interviews with the local people living on the islands. In addition to this, interviews with other tourism stakeholders should be held to examine how local administrators assess the situation and what measures they take.

In this way, it will be possible to determine what other stakeholders think about the issue. It may be possible to find common solutions to problems and to take action in this direction. Thus, sustainable tourism development can be achieved on the islands.

\section{REFERENCES}

Alexis, P. (2017). Over-Tourism and Anti-Tourist Sentiment: An Exploratory Analysis and Discussion. "Ovidius" University Annals, Economic Sciences Series,17(2), p. 288-293. 
Alpar, R. (2013). Çok Değişkenli İstatiksel Yöntemler. Ankara: Detay Yayıncllik.

Alpar, R. (2016). Uygulamalı Istatistik ve Geçerlik-Güvenirlik. Ankara: Detay Yayıncilık.

Alvarez-Sousai A. (2018). The Problems of Tourist Sustainability in Cultural Cities:Socio-Political Perceptions and Interests Management. Sustainability, 10(2), 1-30.

Bimonte, S. \& Punzo, F., L. (2011). Tourism, Residents' Attitudes and Perceived Carrying Capacity with an Experimental Study in Five Tuscan Destinations. International Journal of Sustainable Development, 14(3), p. 242-261.

Bozcaada Belediyesi (2019). Retrieved from: http://www.bozcaada.bel.tr/bozcaada/bozcaadahakkinda/, (Accessed, 15.12.2019).

Brandolini, S. M. D. \& Mosetti, R. (2004). Sustainable tourism development and social carrying capacity: a case-study on the North-Western Adriatic Sea. In book Editors: Pineda F.D. and Brebbia C.A) Sustainable Tourism, WIT PRESS,

Çanakkale travel (2020). Kurban bayramında bozcaada ve gökçeadaya turist akını. Retrieved from: https://www.canakkaletravel.com/haber/kurbanbayraminda- bozcaada-ve-gokceadaya-turist-akini.html, (Accesed, 9.02.2020).

Cittaslow Türkiye (2020). Gökçeada. Retrieved from: https://cittaslowturkiye.org/cittaslow-gokceada (Accesed, 17.09.2020).

CNBC (2020). Two thirds of global population will live in cities by 2050. https://www.cnbc.com/2018/05/17/two-thirdsof-global- $\quad$ population-will-live-in-cities-by-2050-unsays.html (Accesed, 25.08.2020).

CNN (2020). How to stop overtourism. Retrieved from: https://edition.cnn.com/travel/article/howtostopovertourism/index.html (Accessed, 10.09.2020)

Coldwell, W. (2017, 10 Ağustos). First Venice and Barcelona: Now Anti-tourism Marches Spread Across Europe. from: https://www.theguardian.com/travel/2017/aug/10/antitourism-marches-spread-across-europevenicebarcelonal (Accessed, 21.03.2019).

Croes, R., Rivera, M. A., Semrad, K., \& Khalizadeh, J. (2017). Happiness and tourism: Evidence from Aruba, Unpublished Manuscript, The Dick Pope Sr. Institute for Tourism Studies. Orlando, Florida

Doğan, İ. (2015). Farklı Veri Yapısı Ve Örneklem Büyüklüklerinde Yapısal Eşitlik Modellerinin Geçerliği Ve Güvenirliğinin Değerlendirilmesi (Doktora Tezi), Eskişehir Osmangazi Üniversitesi, Eskişehir.

Doxey, G. (1975). " "A. Causation Theory of Visitor-Resident Irritation: Methodology And Research Inference." Proceedings ... of The 6th Annual Conference of the Travel Research Association. San Diego, CA:Travel Research Association, p. 195-98.

Gökçeada Kaymakamlı̆̆ (2020). Retrieved from: http://www.gokceada.gov.tr/turkiyenin-en-buyuk-adasi (Accessed, 15.09.2020).

González, A. T. (2018). Venice: the problem of overtourism and the impact of cruises. Investigaciones Regionales Journal of Regional Research, 42, p. 35-51.
Google (2020). Gökçeada ve Bozcaada Haritası. Retrived from:

https://www.google.com/maps/place/\%C3\%87anakkale +\%C3\%87anakkale+Merkez\%2F\%C3\%87anakkale/ @39.9682827,26.4447457,9.96z/data=!4m5!3m4!1s0x 14b1a9d8214a2f3f:0x8cebeb3703e22f7ff:8m2!3d40.14 $672 ! 4 \mathrm{~d} 26.408587 ? \mathrm{hl}=\mathrm{tr}$

Graefe, A.R., Vaske J.J. \& Kuss, F.R. (1984). Social carrying capacity: An integration and synthesis of twenty years of research. In Leisure Science, 6(4), 395- 431.

Hernández, S.L.Z. Fabíola C.\& de Carvalho,C. (2017). El desarrollo turístico y la utopía de la sustentabilidad en bahia de banderas, Nayarit. Rev. Anais Bras. de Est. Tur./ ABET, Juiz de Fora, 7(3), 29 - 41,

Hürriyet (2020). Herkes Bozcaada'ya akın etti. Retrieved from https://www.hurriyet.com.tr/ekonomi/herkesbozcaadaya-akin-etti-yer-bulamayan-geri-donuyor40443122 (Accesed, 13.02.2020).

İçöz, O., Var, T., İhan, İ. (2009). Turizm Planlaması ve Politikası (2. Baskı). Ankara: Turhan Kitabevi.

ina (2020). Bozcaada'ya turist akını. Retrieved from: http://www.iha.com.tr/haber-bozcaadaya-turist-akini653464/ (Accessed, 10.02.2020).

Joshi, S. \& Dahal,R (2019). Relationship between social carrying capacity and tourism carrying capacity: A Case of annapurna conservation area, Nepal. Journal of Tourism \& Hospitality Education (9), 9-29.

Karagöz, Yalçın (2017). Bilimsel Araştırma Yöntemi. Ankara: Nobel.

Koh, E. \& Fakfare, P. (2020).Overcoming "over-tourism": the closure of Maya Bay. International Journal Of Tourism Cities, 6 (2), p.279-296.

Kušcer, K. Mihalic, T. (2019). Residents' Attitudes towards Overtourism from the Perspective of Tourism Impacts and Cooperation-The Case of Ljubljana. Sustainability, 11 (1823), p. 1-16.

Mauerhofer, W. (2013). Social capital, social capacity and social carrying capacity: Perspectives for the social basics within environmental sustainability, Futures, 53, 63-73.

Muler Gonzalez, V., Coromina, L. and Galí, N. (2018). Overtourism: residents' perceptions of tourism impact as an indicator of resident social carrying capacity - case study of a Spanish heritage town, Tourism Review, 73 (3), p. 277-296.

Oklevika, O., Gossling, S., Hall, C., M., Jacobsene, J. K. S., Grøttef, I., P. \& McCabeg, S. (2019). Overtourism, optimisation, and destination performance indicators: a case study of activities in Fjord Norway. Journal Of Sustainable Tourism, 27 (12), p. 1804-1824.

Perkumienè, D., Pranskūnienè, R. (2019). Overtourism: Between the Right to Travel and Residents' Rights. Sustainability, 11, p. 2138.

Radikal (2020). Tatilciler akın etti halk ekmek bulamadı. Retrieved from: http://www.radikal.com.tr/ekonomi/tatilciler-akin-ettihalk-ekmek-bulamadi-1062086/ (Accessed, 10.02.2020).

Responsible Tourism Partnership (2020). OverTourism: What is it and how do we address it? Retrieved from: 
https://responsibletourismpartnership.org/overtourism/\# $\sim:$ text=Overtourism $\% 20$ describes $\% 20$ destinations $\% 20$ where $\% 20$ hosts, the $\% 20$ experience $\% 20$ has $\% 20$ deterio rated\%20unacceptaby (Accesed, 17.09.2020).

Routledge, P. (2001) 'Selling the rain', resisting the sale: Resistant identities and the conflict over tourism in Goa. Social \& Cultural Geography, 2(2), p. 221-240.

Saveriades, A. (2000). Establishing the social tourism carrying capacity for the tourist resorts of the east coast of the Republic of Cyprus, Tourism Management, 21(2), 147156.

Seraphina, H., Sheeranb, P. \& Pilat, M. (2008). Over-tourism and the fall of Venice as a destination. Journal of Destination Marketing \& Management, 9, p. 374-376.

Şimşek, Ö. F. (2007). Yapısal eşitlik modellemesine giriş, temel ilkeler ve lisrel uygulamaları, Ankara: Ekinoks Yayınları

Smith, M. K., Sziva, I. P. \& Olt, G. (2019). Overtourism and Resident Resistance in Budapest. Tourism Planning \& Development, 16 (4), p. 376-392.

Sousa, R.C., Pereira, L.C.C., Costa, R.M. \& Jiménez, J.A., (2014). Tourism carrying capacity on estuarine beaches in the Brazilian Amazon region. In: Green, A.N. and Cooper, J.A.G. (eds.), Proceedings 13th International Coastal Symposium (Durban, South Africa), Journal of Coastal Research, 70, 545-550, ISSN 0749-0208

Sözcü (2020). Bozcaada yine full çekti. Retrieved from: https://www.sozcu.com.tr/2017/ekonomi/bozcaadayine-full- cekti-1861747/ (Accessed, 7.02.2020).

Tabachnick, B. G., \& Fidell, L. S. (2013). Using multivariate statistics (6th ed.). Boston: Allyn and Bacon.

Tabachninck, G., Barbara; Fidell, S., Linda (2015). Çok Değişkenli İstatistiklerin Kullanımı (Çev. Ed. Mustafa Baloğlu). Ankara: Nobel Akademi.

Tapper, J. (2017). As touting for punt trips becomes a crime, is tourism overwhelming Britain's cities. Retrieved 13.02.2020. h http://www.theguardian.com $\rangle$.
The Conversation (2020). Overtourism: a growing global problem. Retrieved from: https://theconversation.com/overtourism-a-growingglobal-problem-100029 (Accesed, 15.09.2020).

The Guardian (2018a). 'Tourists go home, refugees welcome': why Barcelona chose migrants over visitors. https://www.theguardian.com/cities/2018/jun/25/tourists -go-home-refugees-welcome-why-barcelona-chosemigrants-over-visitors (Accessed, 15.12.2019).

The Guardian (2018b). How tourism is killing Barcelona - a photo essay. https://www.theguardian.com/travel/2018/aug/30/whytourism-is-killing-barcelona-overtourism-photo-essay (Accessed, 15.12.2019).

The Guardian (2020). Overtourism in Europe historic citites sparks backlash. Retrived from: https://www.theguardian.com/world/2020/jan/25/overto urism- in-europe-historic-cities-sparks-backlash. (Accesed, 10.09.2020).

UNWTO (2020). 'Overtourism'? Understanding and Managing Urban Tourism Growth beyond Perceptions. Retrieved from: $\quad$ https://www.eunwto.org/doi/pdf/10.18111/9789284420070 (Accessed 12.09.2020).

Ural, A. \& KIıç, I. (2013). Bilimsel araştırma süreci ve SPSS ile veri analizi. Ankara: Detay Yayınclık.

Vaske JJ. \& Donnelly, MP. (2002). Generalizing the encounternorm-crowding relationship. Leis Sci, 24, 255-269. doi:10.1080/01490400290050718

Wang, Y., Pfister, R.E., Morais, D.B. (2016) RESIDENTS' ATTITUDES TOWARD TOURISM DEVELOPMENT: A CASE STUDY OF WASHINGTON, NC

Zhang, J.J., Wong,, P.P.Y., Lai, P.C. (2018). A geographic analysis of hosts' irritation levels towards mainland Chinese cross-border day-trippers, Tourism Management, 68, 367-374. 